\title{
BOWEL X-RAY ALTERATIONS IN ACUTE HUMAN SCHISTOSOMIASIS
}

\section{Enio Roberto Pietra Pedroso, José Roberto Lambertucci, Manoel Otávio da Costa Rocha, Dirceu Bartolomeu Greco, Cid Sérgio Ferreira, Roberto Sena Rocha e Naftale Katz}

\author{
$A$ radiological study of the small intestine of 17 untreated patients in the acute \\ phase of schistosomiasis was performed. Twelve patients ( $70 \%$ of total) had alterations: \\ nine had clear-cut thickening of the duodenal and jejunal folds, one flocculation, one \\ fragmentation and one thickening of mucosae, flocculation and fragmentation of the \\ barium column. \\ There was no correlation of the gastrointestinal symptomatology (vomiting, \\ diarrhoea, dysentery, hepatomegaly) neither with the parasitological load nor with the \\ $x$-ray alterations.
}

Key words: Schistosoma mansoni. Acute toxemic schistosomiasis. Bowel x-ray alterations.

The post-postural phase of schistosomiasis mansoni has extremely protean clinical manifestations 17 . Usually the acute phase is oligosymptomatic. However, some cases present severe symptons with peculiar clinical and pathological manifestations, defined as the toxemic acute form of the disease.

This paper reports the clinical and radiological aspects of the small intestine within two months after infection in patients with the toxemic acute form of schistosomiasis mansoni.

\section{MATERIAL AND METHODS}

Seventeen patients, infected for the first time, presenting with the toxemic acute form of schistosomiasis mansoni were studied before treatment.

Diagnosis was made based on prior negative coproscopic examination that became positive for $S$. mansoni eggs from 30 to 60 days after the infecting bath, and absence of other parasites in 6 consecutives coproscopic examinations. Also at least one of two clinic-epidemiological criteria namely: absence of prior contact with natural waters contaminated by Schistosoma mansoni cercariae; emergence of a toxic-infectious clinical picture post-contact with infected water consisting of diarrhoeal and/or dysenteric syndrome, cough, fever and hepatosplenomegaly; or hematologic: blood eosinophilia above 1,000 cells $/ \mathrm{mm}^{3} 16$.

Núcleo de Estudos sobre Esquistossomose Mansoni,INERU. Faculdade de Medicina da Universidade Federal de Minas Gerais. Belo Horizonte, Minas Gerais.

Endereço para correspondência: Dr. Ênio Roberto Pietra Pedroso. Departamento de Clínica Médica da Faculdade de Medicina da Universidade Federal de Minas Gerais. Avenida Alfredo Balena 190 - Santa Efigênia. 30.000, Belo Horizonte, Minas Gerais, Brasil.

Financiado parcialmente pelo CNPq, FINEP.

Recebido para publicação em 25/11/85.
The parasitological stool examination was performed by the Kato's method modified by Katz et $\mathrm{al}^{8}$. The patients were divided in 3 groups, according to the average number of eggs of $S$. mansoni per gram of feces: high load $=$ more than 400 eggs/gram of feces (epg), medium load $=$ between 100 and $400 \mathrm{epg}$, low load $=$ less than $100 \mathrm{epg}^{9}$.

After previous consent a conventional radiological barium contrast study of the small bowel was performed in all patients. The small intestine was studied radiographically following the administration of a mixture of 8 ounces by volume of barium sulphate and water to make 16 fluid ounces. The initial film was made at $15 \mathrm{~min}$. and a second after another $15 \mathrm{~min}$. interval. Further film depends on the rate of passage of the barium meal, which usually enables an examination every 30-60 min. Neither saline nor ice water were administered because these preparations in themselves disturb the pattern of the small intestine. In the interpretation of diffuse lesions of the small intestine, larger quantities of barium were preferable so that several intestinal loops of bowel were visualized in continuity at the same time. Small amounts of barium may not reflect the morbid anatomy of the small instestine due to incomplete filling. Frequently, incomplete distention may simulate an abnormality. The larger quantity of barium has the following advantages: 1. fewer films are needed, 2. increased motility is obtained; and, 3. relationship of one intestinal segment to another can be determined (thickness of wall can be evaluated) ${ }^{11}$.

Clinically all patients were well nourished with normal blood protein levels.

The $\mathrm{x}$-rays were analysed blind by three investigators and alterations were considered when at least two of the observations agreed.

The chi-square $\left(\mathrm{X}^{2}\right)$ test was used. The significance level of $\mathbf{5} \%$ was accepted for all tests. 
Pedroso ERP, Lambertucci JR, Rocha MOC, Greco DB, Ferreira CS, Rocha RS, Katz N. Bowel x-ray alterations in acute human schistosomiasis. Revista da Sociedade Brasileira de Medicina Tropical 20: 159-162, Jul-Set, 1987.

\section{RESULTS}

Twelve (70\%) out of 17 patients showed some alteration in the $\mathrm{x}$-ray of the small intestine ranging from flocculation/fragmentation of the barium column to clear-cut mucosal thickening in the duodenal loop and proximal jejunim (Table 1 and Fig. 1).

Among the 12 patients with intestinal radiological abnormalities, nine had also clinical manifestations (diarrhoea, dysentery, nausea, vomiting). On the other hand out of the five patients without $x$-ray alterations, two had gastrointestinal manifestations (Table 2).

There was no correlation of the $\mathrm{x}$-ray alterations, neither with the gastrointestinal symptomatology nor with the parasite load (Table 3).

\section{DISCUSSION}

On reaching their maturity in the portal system, the adult worms of $S$. mansoni, alone or coupled, migrate against the blood stream in direction to the mesenteric venous branches, specially to the inferior mesenteric ones. Once there, the female begins to deposit her eggs. The onset of the oviposition is variable, ranging between the $27^{\text {th }}$ and the $49^{\text {th }}$ days after the infection in humans 562122 .

The manifestations of the toxemic form of $S$. mansoni infection represent an exacerbation of the pre-postural clinical features ${ }^{18}$ and may be confused with typhoid fever and several other diseases ${ }^{19} 23$. Based on the clinical picture presented by the patients and the total and differential leukocyte counts the diagnosis of enteritis associated with Staphylococcus, Salmonella, Shigella, ECHO virus, Poliovirus, Coxsackievirus and Legionnaire's disease are less likely. The coproscopic examinations failed to find evidence of Giardia, Entamoeba, Balantidium, Taenia, Enterobius, Ascaris, Ancylostoma, Necator, and Strongyloides.

In pathological terms toxemic acute schistosomiasis mansoni infection can be characterised by the following events: 1) intense, massive, miliar dissemination of eggs with formation of schistosomal granulomas in the liver, large and small bowel, visceral peritoneum, abdominal and mediastinal lymph nodes, lungs, pleurae and pancreas; 2 ) all the granulomas are in the necrotic-exsudative phase (hyperergic); 3 ) the

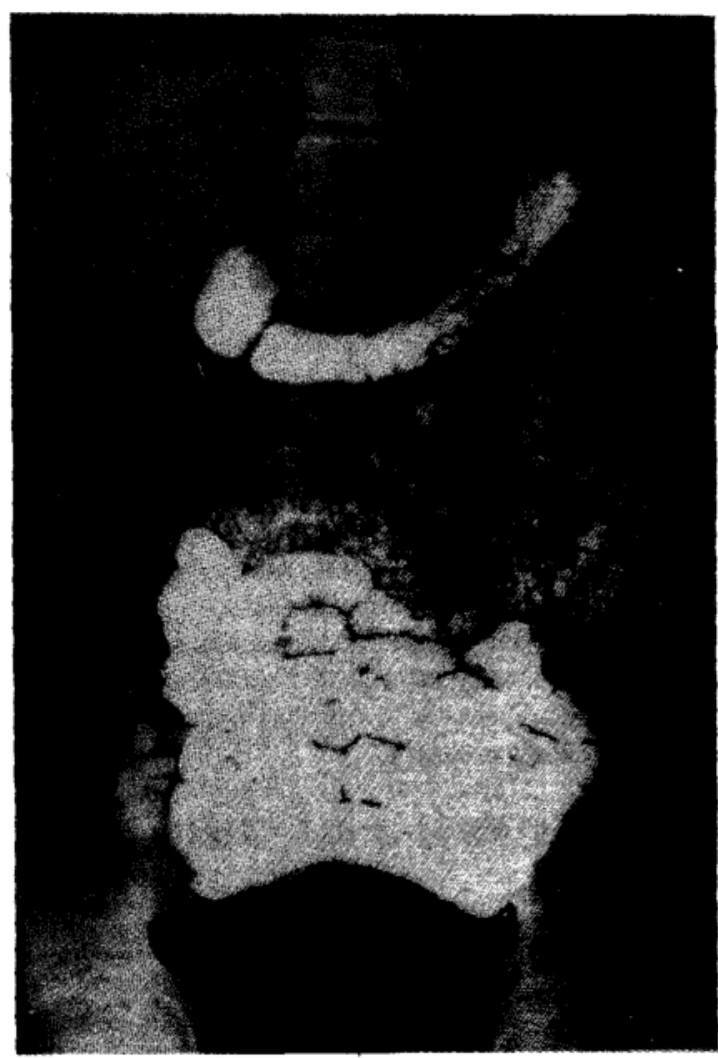

Figure 1 - Asymptomatic patient. Mucosal thickening on the duodenal loop and proximal jejunum with flocculation and fragmentation of the medium.

Table 1 - Alterations observed by the radiological study of the small intestine in 17 patients with the toxemic form of schistosomiasis mansoni.

\begin{tabular}{lc}
\hline Radiological picture & Number of Patients \\
\hline Flocculation of contrast medium & 1 \\
Fragmentation of contrast medium & 1 \\
Mucosal thickening of duodenal loop & 3 \\
Mucosal thickening of proximal jejunum & 1 \\
Mucosal thickening of duodenal loop and proximal jejunum & 5 \\
Mucosal thickening of duodenal loop and proximal jejunum with flocculation and & \\
$\quad$ fragmentation & 1 \\
Normal & 5 \\
Total & 17 \\
\hline
\end{tabular}


Pedroso ERP, Lambertucci JR, Rocha MOC, Greco DB, Ferreira CS, Rocha RS, Katz N. Bowel x-ray alterations in acute human schistosomiasis. Revista da Sociedade Brasileira de Medicina Tropical 20: 159-162, Jul-Set, 1987.

Table 2 - Clinical alterations, radiological features, parasitological load, and number of blood eosinophils in the 17 patients with the acute form of schistosomiasis mansoni.

\begin{tabular}{|c|c|c|c|c|c|c|c|c|c|c|}
\hline \multirow[t]{2}{*}{ Patient } & \multicolumn{4}{|c|}{$\begin{array}{c}\text { Clinical } \\
\text { Alterations }\end{array}$} & \multirow[t]{2}{*}{$\begin{array}{c}\text { Bowel X-Ray } \\
\text { Features }\end{array}$} & \multicolumn{3}{|c|}{$\begin{array}{l}\text { Parasitological } \\
\text { load }\end{array}$} & \multicolumn{2}{|c|}{$\begin{array}{l}\text { Blood Eosinophils } \\
\qquad / \mathrm{mm}^{3}\end{array}$} \\
\hline & $\bar{V}$ & $\bar{D}$ & $D y$ & $\bar{H}$ & & $\overline{H L}$ & $\overline{M L}$ & $\overline{L L}$ & $<1000$ & $>1000$ \\
\hline 1 & + & + & + & + & + & & & + & + & \\
\hline 2 & + & $t$ & + & + & + & & & + & & + \\
\hline 3 & + & + & + & + & + & & & + & & + \\
\hline 4 & + & + & + & + & + & & & + & + & \\
\hline 5 & + & + & + & + & + & & & + & + & \\
\hline 6 & + & + & + & + & + & + & & & & + \\
\hline 7 & + & + & + & + & + & & + & & + & \\
\hline 8 & + & + & + & + & + & & + & & & + \\
\hline 9 & + & + & + & + & + & & + & & + & \\
\hline 10 & - & - & - & - & + & & & + & & + \\
\hline 11 & - & - & - & - & + & & + & & & + \\
\hline 12 & - & - & - & - & + & + & & & & + \\
\hline 13 & + & + & + & + & - & & & + & + & \\
\hline 14 & + & + & + & + & - & & & + & & + \\
\hline 15 & - & - & - & - & - & & + & & & + \\
\hline 16 & - & - & - & - & - & & + & & & + \\
\hline 17 & - & - & - & - & - & + & & & & + \\
\hline
\end{tabular}

V: vomiting, D: diarrhoea, Dy: dysentery, H: hepatomegaly, HL: high load, ML: medium load, LL: low load, +: present, -: absent.

Table 3 - Radiological alterations of small intestine, diarrhoea and parasite load in 17 patients with the acute toxemic form of schistosomiasis mansoni.

\begin{tabular}{lcccccccc}
\hline $\begin{array}{l}\text { Radiological } \\
\text { Features }\end{array}$ & \multicolumn{3}{c}{ Diarrhoea } & & \multicolumn{3}{c}{ Parasitological load } \\
\cline { 2 - 8 }$(a)$ & present & $\begin{array}{c}\text { absent } \\
\text { (b) }\end{array}$ & total & & low & medium & high & total \\
present & 9 & 3 & 12 & 6 & 4 & 2 & 12 \\
absent & 2 & 3 & 5 & 2 & 2 & 1 & 5 \\
Total & 11 & 6 & 17 & 8 & 6 & 3 & 17 \\
\hline
\end{tabular}

$(a-b) X^{2}: 0,67(p>0,05)$

$(a-c) X^{2}: 0,14(p>0,05)$

granulomas are numerous at unusual places, mainly the visceral peritoneum, pancreas and lungs; the hepatic distribution is irregular; 4) in the majority of cases, a superficial disseminated, acute ulcerative enterocolitis coexists with the former events; sometimes it can be slightly haemorrhagic. Usually the intestinal ulcers are small $(1.0-1.5 \mathrm{~mm}$ in diameter), with plain and regular edges. Occasionally these lesions can be larger, with irregular edges, leading to perforation as reported in two autopsy cases ${ }^{16} 18$. The acute catarrhal enterocolitis is characterized by congestion, edema and epithelial scaling, followed by inflammatory infiltration of the lamina propria and submucosa, with neutrophils, eosinophils, lymphocytes and plasma cells, diffuse or focal, almost always intense, and independent of the granulomatous lesion1 2313141519 .

The intestinal symptomatology may be related to alterations in the large bowel and not to the small bowel radiological findings here described. In other words, the pathological alterations are more intense in the large bowel and this dominates the clinical picture. The lack of relation between the $\mathrm{x}$-ray alterations and the parasitological load suggests that a factor other than the mechanical one (obstruction by the presence of eggs) may be responsible for the small intestine involvement.

The deposition of immune complexes in the genesis of these alterations can not be excluded since they have been demonstrated in high concentrations in 
Pedroso ERP, Lambertucci JR, Rocha MOC, Greco DB, Ferreira CS, Rocha RS, Katz N. Bowel x-ray alterations in acute human schistosomiasis. Revista da Sociedade Brasileira de Medicina Tropical 20: 159-162, Jul-Set, 1987.

the initial phase of the disease 1024 and they may deposit in various organs such as kidney, lung, etc. 1234720 .

Thus in the acute form of schistosomiasis mansoni the small intestine lesions may not be directly related to the presence of eggs and/or worms, but may be secondary to a hypersensitivity phenomenon 3718 .

\section{RESUMO}

Foram estudados clínico-radiologicamente 17 pacientes com esquistossomose mansoni aguda, toxêmica, não tratados especificamente. Doze pacientes (70\% do total) possuiam alterações radiológicas: nove com espessamento da mucosa duodenal e jejunal, um com floculação, um com fragmentação e um com espessamento da mucosa, floculação e fragmentação da coluna de bário.

Não houve correlação entre a sintomatologia gastrointestinal (vômito, diarréia, disenteria, hepatomegalia) e a carga parasitária nem com as alterações radiológicas intestinais. Estes dados sugerem a participação do sistema imunológico nas alterações gastrointestinais.

Palavras chaves: Schistosoma mansoni. Esquistossomose toxêmica aguda. Alterações radiológicas intestinais.

\section{REFERENCES}

1. Bogliolo L. Esquistossomose mansoni. Patologia. Revista Brasileira de Malariologia e Doenças Tropicais 11:359-424, 1959.

2. Bogliolo L. Pathological changes in mansoni bilharziasis. Revista de Anatomia Patológica e Oncologia 23: 269297, 1963.

3. Bogliolo L. Patogênese da esquistossomose mansônica. Resenha Clinico-Cientifica 35:97-101, 1966.

4. Falcão A, Gould DB. Immune complex nephropathy in shistosomiasis. Annals of Internal Medicine 83:148-154, 1975.

5. Faust EC, Jones CA, Hoffman WA. Studies on schistosomiasis mansoni in Puerto Rico III - Biological studies. 2 - the mammalian phase of the life cycle. Puerto Rico Journal of Public Health and Tropical Medicine 10:133-196, 1934.

6.1 Girges R. Schistosomasis (Bilharziosis) John Bale Sons \& Danielsson, London, 1934.

7. Greco DB. Infecção por Schistosoma mansoni e deposição de imune-complexos no pulmão: Estudo experimental. Tese de doutorado. Universidade Federal de Minas Gerais, Belo Horizonte, 1980.

8. Katz N, Chaves A, Pellegrino J. A simple device for quantitative stool thick-smear technique in schistosomiasis mansoni. Revista do Instituto de Medicina Tropical de São Paulo 14:397-402, 1972.

9. Lambertucci JR, Pedroso ERP, Souza DWC, Lima DP, Neves J, Salazar HM, Marinho RP, Rocha MOC, Coelho PMZ, Costa MFFL, Greco DB. Therapeutic efficacy of oral oxamniquine in the toxemic form of schistosomiasis mansoni: treatment of eleven individuals from two families and an experimental study. American Journal of Tropical Medicine and Hygiene 29:59-63, 1980.

10. Lawley TJ, Ottesen EA, Hiatt RA, Gazze LA. Circulating immune complexes in acute schistosomiasis. Clinical and Experimental Immunology 37:221-227, 1979.

11. Marshak RH. Roentgen findings in lesions of the small bowel. American Journal of Digestive Diseases 6:1084, 1961.

12. Neves J. Problemas hematológicos na esquistossomose mansoni nas formas toxêmicas e crônicas. Anais Faculdade de Medicina da Universidade Federal de Minas Gerais 22:125-164, 1965.

13. Neves J. Como evoluem os seus pacientes com forma aguda da esquistossomose? In: Simpósio sobre Esquistossomose 2. Prata A \& AboimE (eds) Salvador, p. 192-199, 1970.

14. Neves J, Lobo-Martins NRL, Tonelli E. Forma toxêmica da esquistossomose mansoni. Considerações diagnósticas em torno de 50 casos identificados em Belo Horizonte. Hospital 70:243-263, 1966.

15. Neves J, Raso P. Estudo crítico do tratamento da forma toxêmica da esquistossomose mansoni. Consideraçōes anatomoclínicas. Hospital 65:679-720, 1963.

16. Neves J, Raso P. Estudo anatomoclinico de um caso de forma toxêmica da esquistossomose mansoni que evoluiu para a forma hepatoesplênica em 130 dias (fibrose de Symmers). Revista do Instituto de Medicina Tropical de São Paulo 7:256-266, 1965.

17. Neves J, Raso P, Bogliolo L. Classificação clínicopatológica da esquistossomose mansoni. In: Resumos do Congresso Brasileiro de Hepatologia 4, Belo Horizonte, 1975.

18. Neves J, Raso P, Tafuri W. Estudo anatomoclínico de dois casos de forma toxêmica da Esquistossomose mansoni evoluídos espontaneamente para o óbito. In: Resumos do Congresso da Sociedade Brasileira de Medicina Tropical I, Juiz de Fora, 1965.

19. Neves J, Tonelli E, Carvalho SM. Estudo das manifestaçōes pulmonares da forma toxêmica da esquistossomose mansoni. Revista do Instituto de Medicina Tropical de São Paulo 8:22-29, 1966.

20. Pedroso ERP. Contribuição ao estudo da esquistossomose mansoni humana e experimental. Especial referência às alteraçôes clínico-radiológicas do pulmão após tratamento específico. Pulmão modelo imunopatológico da doença esquistossomótica. Tese de doutorado. F aculdade de Medicina da Universidade Federal de Minas Gerais, Belo Horizonte, MG, 1982.

21. Pifano F. La eosinofilia en la schistosomiasis mansoni. Revista de la Sanidad y Assistencia Social 6:254-296, 1941.

22. Pifano F, Mayer M. Sobre el comportamento de la reacción de Fairley en los estudios clínicos de la schistosomiasis mansoni. Revista de la Sanidad y Assistencia Social 7:379-396, 1942.

23. Pons JA, Hoffman WA. Febrile phenomena in S. mansoni with illustrative cases. Puerto Rico Journal of Public Health and Tropical Medicine 9:1-17, 1933.

24. Santoro F, Bout D, Wattre P, Capron A. Imunocomplexos na esquistossomose. I - Utilização da fixação do complemento para sua deteção. Revista do Instituto de Medicina Tropical de São Paulo 18:152-156, 1976. 